Studia nad Autorytaryzmem i Totalitaryzmem 43, nr 2

Wrocław 2021

https://doi.org/10.19195/2300-7249.43.2.25

JAN GOLA

ORCID: 0000-0001-9236-9259

Uniwersytet Wrocławski

jan.gola@uwr.edu.pl

\title{
Działania organów administracji gospodarczej Polskiej Rzeczypospolitej Ludowej wybrane zagadnienia
}

Słowa kluczowe: organy administracji gospodarczej, Polska Rzeczpospolita Ludowa, prawne formy działania, rady narodowe, Polska Zjednoczona Partia Robotnicza, Komisja Planowania Gospodarczego.

\section{ACTIVITIES OF THE ECONOMIC ADMINISTRATION BODIES IN THE POLISH PEOPLE'S REPUBLIC: SELECTED ISSUES}

Abstract

The article presents the basic assumptions of the economic administration system in the Polish People's Republic, including the functioning of national councils in a centralized economy. The legal forms of action used by economic administration bodies and their impact on the economy are characterized. Attention is also paid to state-owned enterprises, which in the communist state constituted a kind of foundation for the economic system. In addition, there is a reference to economic planning, which contributed to the long-term poor economic condition of the state.

Keywords: economic administration bodies, Polish People's Republic, legal forms of operation, national councils, Polish United Workers' Party, Economic Planning Commission. 


\section{Wprowadzenie}

W reżimie socjalistycznym w Polsce organy administracji gospodarczej zajmowały istotne miejsce w systemie administracji publicznej. To na nich w dużej mierze spoczywał ciężar zarządzania gospodarka narodową państwa. Mimo swoistego systemu gospodarczego często były zobligowane do prawidłowego wydatkowania środków publicznych, realizując jednocześnie założenia zasad prawa zarządzania gospodarką narodową, między innymi odnoszących się do prawidłowego gospodarowania mieniem publicznym ${ }^{1}$. Nie było to jednak efektywne i charakteryzowało się wieloma nieścis Wskazane organy organizowały ponadto państwowe jednostki prowadzące działalność gospodarczą oraz wpływały bezpośrednio na ich działalność. Już na wstępie warto zaznaczyć, że podstawą dla wyznaczania zadań państwowym podmiotom gospodarczym były dyrektywne akty planistyczne, które miały w założeniu wyeliminować niedogodności wynikające ze spontanicznie działających mechanizmów rynkowych ${ }^{2}$. Przedstawiciele doktryny prawa administracyjnego zwracali uwagę na to, że charakter prawodawczy planów gospodarczych określał całokształt działalności państwa w sferze gospodarki i de facto wpływa na rozwój społeczno-gospodarczy ${ }^{3}$. W kontekście tytułowej problematyki istotne jest też, że w konstytucji lipcowej zostały zawarte podstawowe założenia ustroju gospodarczego $\mathrm{PRL}^{4}$, a podstawę ekonomiczną państwa socjalistycznego stanowiła społeczna własność produkcji ${ }^{5}$.

Celem artykułu jest przedstawienie systemu organów administracji gospodarczej PRL, a także podejmowanych przez nie działań. Wyodrębniona zostanie specyfika planów gospodarczych i ich wpływ na gospodarkę.

${ }^{1}$ Szerzej zob. A. Chełmoński, Swoiste zasady administracyjnego prawa gospodarczego, [w:] A. Borkowski et al., Administracyjne prawo gospodarcze, Wrocław 2009, s. $61 \mathrm{n}$.

2 T. Kocowski, Od administracji zarządzającej do administracji nadzorczej, [w:] Administracja publiczna pod rządami prawa: księga pamiatkowa z okazji 70-lecia urodzin prof. zw. dra hab. Adama Błasia, red. J. Korczak, Wrocław 2016, s. 245-246.

3 Ibidem, s. 246.

${ }^{4}$ Zgodnie z tym aktem prawnym gospodarka oparta była na uspołecznionych środkach produkcji, wymiany, komunikacji i kredytu, rozwijaniu życia gospodarczego i kulturalnego kraju na postawie narodowego planu gospodarczego, w szczególności przez rozbudowę państwowego przemysłu socjalistycznego, rozstrzygającego czynnika w przekształcaniu stosunków społeczno-gospodarczych. Stwierdzono także, że państwo posiada monopol handlu zagranicznego, a zasadnicznym celem planowej polityki gospodarczej Polskiej Rzeczypospolitej Ludowej jest stały rozwój sił wytwórczych kraju, nieustanne podnoszenie poziomu życiowego mas pracujących, umacnianie siły, obronności i niezależności ojczyzny. Zob. art. 7 Konstytucji Polskiej Rzeczypospolitej Ludowej uchwalonej przez Sejm Ustawodawczy w dniu 22 lipca 1952 roku (Dz.U. z 1952 r. Nr 33, poz. 232 ze zm.). Por. A. Chełmoński, Instytucje administracyjnoprawne w zarządzaniu gospodarka narodowa, [w:] System prawa administracyjnego, t. 4, red. T. Rabska, Wrocław 1980, s. 429 n.

5 M. Błachucki, Liberalizacja zasad działalności gospodarczej, [w:] Transformacja systemowa w Polsce, red. K. Żurkowska, Warszawa 2010, s. 374. 


\section{Organy administracji gospodarczej Polskiej Rzeczpospolitej Ludowej}

Już w tym miejscu należy zaznaczyć, że doktryna prawa administracyjnego wyróżnia podstawowe rodzaje organów będące skutkiem podziału całości administracji publicznej: administracji państwowej, rządowej, samorządu terytorialnego oraz samorządu zawodowego ${ }^{6}$. W PRL organy administracji gospodarczej zajmowały szczególne miejsce. Organizowaniem stosunków gospodarczych zajmowały się organy władzy oraz administracji państwowej. Właśnie z tej drugiej kategorii można wyodrębnić takie instruktywne przykłady, jak organy wykonawczo-zarządzające (przykładem była Rada Ministrów); terenowe organy administracji państwowej (wojewodowie, prezydenci, naczelnicy; podlegały im przedsiębiorstwa państwowe oraz terenowe zakłady państwowe) ${ }^{7}$; niezespolone organy administracji państwowej (podlegały koordynacji sprawowanej przez rady narodowe) ${ }^{8}$.

Ważną rolę pełniły także rady narodowe. Najważniejszym aktem prawnym odnoszącym się do ich funkcjonowania była ustawa z dnia 25 stycznia 1958 roku o radach narodowych ${ }^{9}$. Rady były ciałami kolegialnymi i działały na sesjach lub przez swoje organy - komisje oraz prezydium ${ }^{10}$. Celem wprowadzenia tego aktu do systemu prawnego PRL było określenie zakresu działania tych podmiotów i dalszego rozszerzenia ich uprawnień. Wskazano także na umocnienia kwestii samodzielności przy równoczesnym ustaleniu uprawnień nadzorczych, niezbędnych dla realizacji jednolitej polityki w państwie ${ }^{11}$. Normodawca wyodrębnił rady narodowe stopnia najniższego (gromadzkie, miejskie, dzielnicowe) ${ }^{12}$.

${ }^{6}$ Por. W. Chróścielewski, Organ administracji publicznej w postępowaniu administracyjnym, Warszawa 2002, s. 12 n.; J. Jagoda, M. Jerominek, Pojęcie organu w prawie samorzadowym, [w:] Koncepcja systemu prawa administracyjnego. Zjazd Katedr Prawa Administracyjnego i Postępowania Administracyjnego, Zakopane 24-27 września 2006 r., red. J. Zimmermann, Warszawa 2007, s. 195 n.; K. Kiczka, Administracji gospodarcza - pojęcie, [w:] J. Grabowski et al., System Prawa Administracyjnego, t. 8A. Publiczne prawo gospodarcze, Warszawa 2018.

7 Zob. Z. Leoński, Terenowe organy administracji państwowej szczególnej w systemie rad narodowych, „Państwo i Prawo” 198, nr 11, passim.

8 Z. Rybicki, Administracja gospodarcza w PRL, Warszawa 1975, s. 78.

${ }^{9}$ Dz.U. z 1958 r. Nr 5, poz. 16. Można wskazać także na uchwaloną przez Krajową Radę Narodową 11 września 1944 roku ustawę o organizacji i zakresie działania rad narodowych (Dz.U. z 1944 r. Nr 5, poz. 22). Ustawodawca stwierdził, że rady narodowe to tymczasowe organy ustawodawcze i samorządowe na oswobodzonych od okupanta terenach Rzeczypospolitej Polskiej, funkcjonujące w tej formie do czasu powołania stałej politycznej reprezentacji narodu.

10 Z. Rybicki, Działalność i organizacja rad narodowych w PRL, Warszawa 1965, s. 263.

11 Zob. wstęp do ustawy o radach narodowych.

12 Zob. I. Lewandowska-Malec, Dwie koncepcje udziału rad narodowych w życiu publicznym PRL, „Państwo i Społeczeństwo” 2001, nr 1, s. 123-139; A. Wendel, Rozwój rad narodowych w Polsce Ludowej, „Przegląd Historyczny” 1955, nr 44, s. 543-560; Z. Leoński, Ewolucja rad narodowych w Polsce Ludowej, „Ruch Prawniczy, Ekonomiczny i Socjologiczny” 1984, nr 4, s. 1-16; W. Kozyra, Ustrój administracji państwowej w Polsce w latach 1944-1950, „Czasopismo Prawno-Historyczne” 
Odpowiedzialne były one za troszczenie się o zaspokajanie potrzeb bytowych, organizowanie działalności produkcyjnej mieszkańców wsi, a także za funkcjonowanie punktów usługowych i handlowych. Kolejną grupę stanowiły rady stopnia powiatowego, które posiadały kompetencje w rozstrzyganiu indywidualnych spraw administracyjnych. Były one między innymi organizatorami sieci placówek oświaty, służby zdrowia i opieki społecznej, a także koordynowały usługi dla ludności i organizowały produkcję rolną. Do trzeciej grupy zaliczyć można rady stopnia wojewódzkiego. Koordynowały one działalność wszystkich przedsiębiorstw terenowych, bez względu na stopień ich podporządkowania. Zarządzały także jednostkami produkcyjnymi, usługowymi oraz innymi, których zakres działania przekraczał obszar powiatu. Ponadto posiadały uprawnienia w zakresie koordynowania działalności przedsiębiorstw kluczowych ${ }^{13}$.

Warto także wskazać na rolę, jaką miała PZPR i jej wpływ na organy administracji gospodarczej. Wskazywano, że celem jej działalności był rozwój kraju, $\mathrm{w}$ tym między innymi

troska o rozwój demokratycznych instytucji polityczno-prawnych, służących pośredniemu (przedstawicielskiemu) i bezpośredniemu udziałowi ludzi pracy w rządzeniu; zapewnienie realizacji założeń politycznych w węzłowych sprawach społecznego, kulturalnego i gospodarczego rozwoju kraju; stwarzanie niezbędnych warunków efektywnego działania poszczególnych ogniw i całości aparatu państwowego; sprawowanie kontroli nad działalnością organów oraz osób sprawujących odpowiedzialne funkcje w aparacie państwowym ${ }^{14}$.

\section{Prawne formy działania organów administracji gospodarczej w sferze zarządzania gospodarką}

Wydaje się, że kluczową rolę w sferze zarządzania gospodarką przez organy administracji gospodarczej w PRL odgrywały plany gospodarcze ${ }^{15}$, które de facto przyczyniały się do katastrofalnej sytuacji ekonomicznej państwa. Zawierały one obowiązujące dla adresatów postanowienia, ustalające ich kierunek działania, a także określające cele, do jakich dany organ ma zmierzać w swojej pracy. Ponadto warto zaakcentować, że ich realizacja gwarantowana była środkami politycznymi, ekonomicznymi i prawnymi, w zależności od potrzeb oraz działalności państwa socjalistycznego. Były one uchwalane przez organy władzy państwowej (narodowe i terenowe), natomiast w ramach ustaleń planów podstawowych przez

2011, nr 1, s. 171-191; W. Morawski, Zagadnienia rad narodowych w Polsce Ludowej, Warszawa 1954, passim; J. Starościak, Rady narodowe. Ustrój i działalność, Warszawa 1971, passim; J. Jakimowski, E. Trznadel, Zarys organizacji rad narodowych i samorzadu terytorialnego, Wrocław 1946, passim.

13 Z. Rybicki, Administracja gospodarcza w PRL, s. 139-140.

14 Z. Rybicki, Administracja gospodarcza europejskich krajów RWPG, Wrocław 1975, s. 73-74.

15 Szerzej o genezie planowania zob. R. Stasikowski, O istocie funkcji planistycznej administracji publicznej, ,Przegląd Prawa Publicznego” 2009, nr 5, s. 23-39. 
organy, które były upoważnione do wydawania aktów o charakterze wykonawczym $^{16}$. Można skonstatować w tym miejscu, że PZPR ustalała de facto „kierunek” działań gospodarczych państwa. Przedstawiciele doktryny prawa administracyjnego tworzący w tamtym okresie podkreślali, że partia wskazywała „najsłuszniejsze dla danego etapu rozwoju metody i formy organizacyjne zarządzania gospodarką narodową. Państwo jest instrumentem realizacji zadań politycznych i dlatego też wskazania partii znajdują swoje odzwierciedlenie w aktach państwowych oraz działalności całego systemu organów pańtwa socjalistycznego"17.

Wskazywano, że

konkretność normy planu gospodarczego, którą można nazwać normą planową, odróżnić należy od indywidualnego aktu prawnego, a w szczególności od aktu administracyjnego. Norma planowa ustala skonkretyzowane w czasie, wyrażone w liczbach, a często i umiejscowione terytorialnie generalne zadania określonych jednostek powołanych do realizacji planu. Ta konkretność normy planowej odróżnia ją od abstrakcyjności normy tradycyjnej i stanowi najistotniejszy element nowego jej charakteru ${ }^{18}$.

Z. Rybicki zauważa ponadto, że wskazana konkretność normy planowej nie jest związana $\mathrm{z}$ rozstrzyganiem zindywidualizowanych sytuacji $\mathrm{w}$ celu wywołania określonych skutków prawnych, które charakterystyczne są dla aktów administracyjnych ${ }^{19}$. Autor podkreślał:

wyodrębnienie zasady planowego zarządzania oznacza przede wszystkim, że dla właściwego przebiegu budownictwa ustroju socjalistycznego istnieć musi system gospodarki planowej. Konieczność przyjęcia tego systemu jako metody realizacji zadań ekonomicznych wynika z wymogów obiektywnych praw ekonomicznych, ukształtowanych w socjalistycznym systemie społeczno gospodarczym. Planowe zarządzanie jest zasadą organizacji i funkcjonowania socjalistycznego aparatu państwowego. Stwarza to konieczność odpowiedniego do wymogów tej zasady zorganizowania organów władzy i administracji oraz wyposażenia ich w skuteczne formy i metody działania ${ }^{20}$.

Przedstawiciele doktryny prawa administracyjnego podkreślali, że akty planowania posiadają swoisty charakter jako źródła prawa, który wywodzili z tego, że w ich treści występują normy o zróżnicowanym charakterze - ogólne, indywidualne, informacyjne, o imperatywnym charakterze, a także oddziałujące pośrednio. Charakteryzowały się one różnorodnością - miały cechy aktów zewnętrznych lub wewnętrznych oraz ulegały dezaktualizacji ${ }^{21}$. Warto też

16 Z. Rybicki, Zarządzanie gospodarka socjalistyczna na tle przeksztatceń ustrojowych, Warszawa 1969, s. 270.

17 Z. Rybicki, Zarzadzanie gospodarka narodowa w PRL. Zagadnienia administracyjno-prawne, Warszawa 1963, s. 93.

18 Z. Rybicki, Zarządzanie gospodarka socjalistyczną..., s. 270-271.

19 Ibidem, s. 271.

20 Z. Rybicki, Administracyjno-prawne zagadnienia gospodarki planowej, Warszawa 1968, s. 112.

${ }^{21}$ M. Stahl, Szczególne prawne formy działania administracji, [w:] A. Błaś et al., Prawne formy działania administracji. System Prawa Administracyjnego, t. 5, Warszawa 2013. Autorka przytacza 
zaznaczyć, że plany gospodarcze były przyjmowane w formie uchwał sejmu (na przykład uchwała Sejmu Polskiej Rzeczypospolitej Ludowej z dnia 12 lipca 1957 roku o planie rozwoju gospodarczego w latach 1956-1960) ${ }^{22}$.

Z planami gospodarczymi w PRL bezpośrednio powiązane były inne formy stanowiące podstawę działania organów administracji gospodarczej. Zaliczano do nich akty generalne, które również wtedy odgrywały najistotniejszą rolę. Wśród nich wyodrębniano: akty normatywne, które stanowiły podstawę prawną aktów o charakterze indywidualnym; akty normatywne nie stanowiące źródeł prawa, które zawierały na przykład normy planowe i techniczne; wytyczne; statuty wewnętrzne organów przedsiębiorstw państwowych lub zakładów. Kolejną grupę stanowiły akty prawne indywidualne - wydawane na podstawie aktów normatywnych należących do źródeł prawa lub statutów wewnętrznych. Zaliczano do nich: umowy cywilnoprawne; akty administracyjne (w tym decyzje administracyjne); postanowienia podejmowane w sprawach o charakterze proceduralnym oraz materialno-technicznym; polecenia administracyjne; ustalenia wiążących opinii lub wyrażanie zgody; udzielanie wiążących zaleceń, zawierających obowiązek konkretnego działania. Wyodrębniano również zawieranie porozumień administracyjnych (w tym porozumień dotyczących koordynacji działalności gospodarczej), a także stosowanie niewładczych form działania i podejmowanie czynności materialno-technicznych ${ }^{23}$.

W tym miejscu trzeba jeszcze wspomnieć, że organy administracji gospodarczej PRL wywierały realny wpływ na działalność przedsiębiorstw państwowych, które posiadały osobowość prawną i stanowiły swoistą podstawę funkcjonowania gospodarki państwa ${ }^{24}$. Do aktów prawnych regulujących pozycję tych podmiotów można zaliczyć dekret z dnia 26 października 1950 roku o przedsiębiorstwach państwowych ${ }^{25}$, w którym znalazły się główne założenia funkcjonowania rzeczonych przedsiębiorstw. Warto podkreślić, że zgodnie z tym aktem przedsiębiorstwa państwowe tworzone były dla wykonywania planów gospodarczych. Ich utworzenie następowało $\mathrm{w}$ drodze zarządzenia właściwego ministra w porozumieniu z ministrem finansów i za zgodą przewodniczącego Państwowej Komisji Planowania Gospodarczego ${ }^{26}$.

między innymi poglądy E. Ochendowskiego. Zob. idem, Prawo administracyjne. Część ogólna, Toruń 2004, s. 140. Zob. też. A. Chełmoński, Koordynacja gospodarcza, [w:] System Prawa Administracyjnego, t. 4, red. T. Rabska, Warszawa 1980, s. 478; A. Żywicka, Nadzór nad wyrobami podlegajacymi dyrektywom ,nowego podejścia” w Polsce - kilka refleksji o koordynacji działań organów nadzoru, „Prawo” 2019, nr 329, s. 435.

22 Dz.U. z 1967 r. Nr 40, poz.179.

23 Z. Rybicki, Zarzadzanie gospodarka socjalistyczna..., s. 266-267.

24 Szerzej na temat przedsiębiorstw państwowych zob. T. Kocowski, Komercjalizacja przedsiębiorstw państwowych a właścicielskie uprawnienia nadzorcze administracji publicznej, „Prace Naukowe Uniwersytetu Ekonomicznego we Wrocławiu” 2014, nr 362, s. 196-210.

25 Dz.U. z 1950 r. Nr 49, poz. 439. Dalej: DPP.

26 Przedsiębiorstwa państwowe podlegały wpisowi do rejestru przedsiębiorstw państwowych i nabywały osobowość prawną z dniem wpisu. Zob. art. 1 i 4 DPP. 
Z punktu widzenia tematu artykułu warto skonstatować, że najważniejsza rola w zarządzaniu omawianym podmiotem prawa przypadała dyrektorowi danego przedsiębiorstwa państwowego ${ }^{27}$. Kierował on samodzielnie daną jednostką i za nią odpowiadał. Ciekawe może wydawać się to, że dyrektor traktowany był przez doktrynę i prawodawcę w systemie komunistycznym jako organ administracji gospodarczej ${ }^{28}$. Ponadto wydawał decyzje administracyjne kierowane na zewnątrz kierowanej przez niego jednostki. Wskazywano, że całe przedsiębiorstwo nie może być uważane jako organ administracji państwowej, ponieważ załoga przedsiębiorstwa powołana jest tylko do bezpośredniej działalności produkcyjnej, a nie do jej zarządzania ${ }^{29}$.

Dyrektor przedsiębiorstwa państwowego zależny był od naczelnego dyrektora zjednoczenia ${ }^{30}$, a także był członkiem kolegium zjednoczenia ${ }^{31}$. Samo zaś zjednoczenie różni się od

przedsiębiorstwa wielozakładowego z jednej strony wyższym stopniem koncentracji produkcji, a z drugiej strony mniejszą intensywnością powiązań kooperacyjnych ze zgrupowanymi jednostkami. Stopień intensywności tych powiązań jest przy tym niejednolity — począwszy od zarządzania przedsiębiorstwami o bardzo ograniczonej autonomii (a więc zbliżając się do formy przedsiębiorstwa wielozakładowego), aż do zarządu w wyższym stopniu usamodzielnionymi przedsiębiorstwami ${ }^{32}$.

\section{Wnioski}

W PRL działania organów administracji gospodarczej charakteryzowały się swoistym podporządkowaniem aktualnym założeniom planów gospodarczych i polityki PZPR. Wydatkowanie środków publicznych nie było więc często racjonalne i efektywne. Organy te zajmowały istotne miejsce w strukturach administracji publicznej państwa autorytarnego. System gospodarki był zależny od podejmowanych decyzji przez te podmioty. Wpływały na funkcjonowanie przedsiębiorstw państwowych i wytaczały kierunki ich działań. Brak mechanizmów

27 Zgodnie z art. 14 DPP powoływał go i odwoływał właściwy minister. Natomiast dyrektora przedsiębiorstwa podlegającemu terenowemu jednolitej władzy państwowej powoływało i odwoływało prezydium rady narodowej za zgodą właściwego ministra.

28 Zob. Z. Niedbała, Dyrektor przedsiębiorstwa państwowego. Stanowisko prawne w świetle zasady jednoosobowego kierownictwa, Poznań 1973, s. 21 n.

29 Z. Rybicki, Zarzadzanie gospodarka narodowa..., s. 219 n.

30 Zob. uchwała nr 383 Rady Ministrów z dnia 7 grudnia 1966 roku w sprawie zasad organizacji i funkcjonowania zjednoczeń (Monitor Polski z 1966 r. Nr 69, poz. 327 ze zm.).

31 Szerzej na temat zjednoczeń zob. Z. Niedbała, Tryb podejmowania i charakter prawny decyzji powolujacych i odwolujacych dyrektorów przedsiębiorstw państwowych, „Ruch Prawniczy, Ekonomiczny i Socjologiczny” 1972, nr 1, s. 43-54; idem, Nowe elementy statusu pracowniczego dyrektora przedsiębiorstwa państwowego, „Ruch Prawniczy, Ekonomiczny i Socjologiczny” 1983, nr 1, s. 1-11.

32 J. Wierzbicki, Główne kierunki przebudowy zjednoczeń a zasady rozrachunku gospodarczego, „Ruch Prawniczy, Ekonomiczny i Socjologiczny” 1965, nr 1, s. 244. 
wolnorynkowych i zbyt duża rola organów administracji publicznej w gospodarce doprowadziły de facto do złej sytuacji ekonomicznej kraju. Ponadto kierownicze stanowiska w scentralizowanej administracji publicznej obejmowały osoby często nieprzygotowane i bez odpowiedniego wykształcenia. Nie stosowały one podstawowych założeń zasady prawidłowego gospodarowania mieniem publicznym, co w dłuższej perspektywie także miało wpływ pośrednio na na rozwój ekonomiczny kraju.

Zadania i funkcje administracji publicznej w gospodarce scentralizowanej i planowej nie charakteryzowały się istnieniem sprawnie funkcjonującego systemu administracyjnoprawnych środków wydatkowania środków publicznych. Nie istniała prawidłowo działająca kontrola społeczna nad wykonywaniem władzy publicznej $^{33}$, a tym samym nie sprzyjało to budowie społeczeństwa obywatelskiego. Dochodziło do rozwoju wielu patologii w administracji publicznej, między innymi do korupcji i nepotyzmu. Pozytywne zmiany w omawianej sferze nastąpiły dopiero w 1989 roku wraz z narodzinami w Polsce demokratycznego państwa prawnego.

\section{Bibliografia}

Błachucki M., Liberalizacja zasad działalności gospodarczej, [w:] Transformacja systemowa w Polsce, red. K. Żurkowska, Warszawa 2010.

Chełmoński A., Instytucje administracyjnoprawne w zarządzaniu gospodarka narodowa, [w:] System prawa administracyjnego, t. 4, red. T. Rabska, Wrocław 1980 .

Chełmoński A., Koordynacja gospodarcza, [w:] System Prawa Administracyjnego, t. 4, red. T. Rabska, Warszawa 1980.

Chełmoński A., Swoiste zasady administracyjnego prawa gospodarczego, [w:] A. Borkowski, A. Chełmoński, M. Guziński, K. Kiczka, L. Kieres, T. Kocowski, M. Szydło, Administracyjne prawo gospodarcze, Wrocław 2009.

Chróścielewski W., Organ administracji publicznej w postępowaniu administracyjnym, Warszawa 2002.

Jagoda J., Jerominek M., Pojęcie organu w prawie samorzadowym, [w:] Koncepcja systemu prawa administracyjnego. Zjazd Katedr Prawa Administracyjnego i Postępowania Administracyjnego, Zakopane 24-27 września 2006 r., red. J. Zimmermann, Warszawa 2007.

Jakimowski J., Trznadel E., Zarys organizacji rad narodowych i samorzadu terytorialnego, Wrocław 1946.

Kiczka K., Administracji gospodarcza - pojęcie, [w:] J. Grabowski, L. Kieres, A. Walaszek-Pyzioł, M. Biliński, R. Blicharz, T. Długosz, K. Horubski, K. Kiczka, T. Kocowski, M. Szydło, A. Żurawik, System Prawa Administracyjnego, t. 8A. Publiczne prawo gospodarcze, Warszawa 2018.

Kozyra W., Ustrój administracji państwowej w Polsce w latach 1944-1950, „Czasopismo Prawno-Historyczne" 2011, nr 1.

33 G. Wróblewska, Komitety kontroli społecznej, ,Ruch Prawniczy, Ekonomiczny i Socjologiczny” 1979, nr 3, s. 107-123. 
Kocowski T., Komercjalizacja przedsiębiorstw państwowych a właścicielskie uprawnienia nadzorcze administracji publicznej, „Prace Naukowe Uniwersytetu Ekonomicznego we Wrocławiu” 2014, nr 362.

Kocowski T., Od administracji zarządzającej do administracji nadzorczej, [w:] Administracja publiczna pod rzadami prawa: ksiegga pamiatkowa z okazji 70-lecia urodzin prof. zw. dra hab. Adama Błasia, red. J. Korczak, Wrocław 2016.

Leoński Z., Ewolucja rad narodowych w Polsce Ludowej, „Ruch Prawniczy, Ekonomiczny i Socjologiczny" 1984, $\mathrm{nr} 4$.

Leoński Z., Terenowe organy administracji państwowej szczególnej w systemie rad narodowych, „Państwo i Prawo” 1984, nr 11.

Lewandowska-Malec I., Dwie koncepcje udziału rad narodowych w życiu publicznym PRL, „Państwo i Społeczeństwo" 2001, nr 1.

Morawski W., Zagadnienia rad narodowych w Polsce Ludowej, Warszawa 1954.

Niedbała Z., Dyrektor przedsiębiorstwa państwowego. Stanowisko prawne w świetle zasady jednoosobowego kierownictwa, Poznań 1973.

Niedbała Z., Nowe elementy statusu pracowniczego dyrektora przedsiębiorstwa państwowego, „Ruch Prawniczy, Ekonomiczny i Socjologiczny" 1983, nr 1.

Niedbała Z., Tryb podejmowania i charakter prawny decyzji powołujacych i odwolujacych dyrektorów przedsiębiorstw państwowych, „Ruch Prawniczy, Ekonomiczny i Socjologiczny” 1972, nr 1.

Ochendowski E., Prawo administracyjne. Część ogólna, Toruń 2004.

Rybicki Z., Administracja gospodarcza europejskich krajów RWPG, Wrocław 1975.

Rybicki Z., Administracja gospodarcza w PRL, Warszawa 1975.

Rybicki Z., Administracyjno-prawne zagadnienia gospodarki planowej, Warszawa 1968.

Rybicki Z., Działalność i organizacja rad narodowych w PRL, Warszawa 1965.

Rybicki Z., Zarządzanie gospodarka narodowa w PRL. Zagadnienia administracyjno-prawne, Warszawa 1963.

Rybicki Z., Zarzadzanie gospodarka socjalistyczna na tle przeksztatceń ustrojowych, Warszawa 1969.

Stahl M., Szczególne prawne formy działania administracji, [w:] A. Błaś, J. Boć, M. Stahl, K. Ziemski, Prawne formy działania administracji. System Prawa Administracyjnego, t. 5, Warszawa 2013.

Starościak J., Rady narodowe. Ustrój i działalność, Warszawa 1971.

Stasikowski R., O istocie funkcji planistycznej administracji publicznej, „Przegląd Prawa Publicznego" 2009, nr 5.

Wendel A., Rozwój rad narodowych w Polsce Ludowej, „Przegląd Historyczny” 1955, nr 44.

Wierzbicki J., Główne kierunki przebudowy zjednoczeń a zasady rozrachunku gospodarczego, „Ruch Prawniczy, Ekonomiczny i Socjologiczny” 1965, nr 1.

Wróblewska G., Komitety kontroli społecznej, „Ruch Prawniczy, Ekonomiczny i Socjologiczny” 1979 , nr 3 .

Żywicka A., Nadzór nad wyrobami podlegajacymi dyrektywom „nowego podejścia” w Polsce kilka refleksji o koordynacji działań organów nadzoru, „Prawo” 2019, nr 329. 